\title{
The Sense of Self-efficacy - An Arab Teacher in a Jewish School
}

\author{
Baratz Lea ${ }^{1} \&$ Efrat Kass ${ }^{1}$ \\ ${ }^{1}$ Achva academic College, Israel \\ Correspondence: Dr. Baratz Lea, Achva academic College, Israel.
}

Received: September 5, 2016

Accepted: October 4, 2016

Online Published: October 7, 2016

doi:10.20849/aes.v1i2.75

URL: http://dx.doi.org/10.20849/aes.v1i2.75

\begin{abstract}
This study seeks to present through a case study a new phenomenon that is still limited in scope, but is taking shape within the Israeli education system. It is that of Muslim Arab women who choose to teach in Israeli Jewish schools. The article presents the case study of such a teacher. The purpose of the article is to analyze the subject's perceptions, beliefs and feelings in the context of her place within the Israeli education system and the understanding of the mechanisms she employs to reinforce her sense of self-efficacy in coping with the identity conflict deriving from being an Arab teacher in a Jewish high school. The study is interpretative in nature and examines how the Muslim Arab teacher perceives her integration while relating to the experiences with various bodies (administration, colleagues, students and parents). The study is based on an open in-depth interview with the teacher. Findings indicated how tools relating to her personal sense of self-efficacy help her bridge the gap between her professional and personal identities.
\end{abstract}

Keywords: personal identity, professional identity, self-efficacy, home, Jewish school female Arab teacher

\section{Research Context and Aims}

The article presents the case of an Arab teacher who teaches a technological subject matter in a Jewish school. The aim of the article is to analyze her perceptions, beliefs and feelings in the context of her place in the Israeli education system. It also seeks to understand the mechanisms she uses to strengthen her sense of self-efficacy in order to cope successfully with the identity conflict arising from the fact she is an Arab teacher in a Jewish school.

\section{Theoretical Framework}

The study takes place in a multicultural educational context of minority groups, and thus the article begins with a description of the structure of the Israeli education system. Following that, it presents the concept of social identity and finally the theory of self-efficacy in an intercultural context.

\section{A. The Israeli education system}

Israeli society is highly heterogeneous. It is composed of two major populations: $80 \%$ Jews and approximately $20 \%$ Arabs, of whom 18\% are Muslim and $2 \%$ are Christian (CBS, 2012), and other smaller minorities. The Arabs living in Israel are simultaneously Israeli and Palestinian and they see themselves as an integral part of the Palestinian people (Al, Haj, 1997; Peres and Ben-Rafael, 2006). The Arabs living in Israel within the 1948 borders are usually referred to by the Jewish majority as "Israeli Arabs" or "Arab Israelis", but the term is a political issue that has been addressed by Arab scholars, writers and intellectuals. (Peres and Ben-Rafael, 2006; Kashua, 2005). Most of them prefer to be considered Palestinian citizens of Israel or to be called 1948 Palestinians, or Palestinian Israelis (Al-Haj, 1997, 2002).

The structure of the education system is sectorial (general Jewish, religious Jewish, and Arab). This arrangement more or less prevents the formation of classes of mixed nations and religions, in other words, for the most part; Jews and Arabs do not study in the same class during their school years. In Israel, there are only five bi-national and multi-religion schools. In Teacher Education colleges budgeted by the Ministry of Education, cultural segregation was maintained until recent decades, based on the notion that preparation for teaching is culture- and language-based and so it was proper to make sure that each sector - Jewish and Arab - could each prepare its teachers according to its needs. Today, however, Jews and Arabs study together in institutions of higher learning. Despite the many debates within the discourse of multicultural/intercultural education about the proper and effective ways to promote relationships of mutual respect between members of different cultural groups, there is 
a consensus that transverses ideological and academic camps regarding the need to create in-depth, ongoing contact between members of different cultural groups, whether this be constant in the permanent school settings or less continuous but more intensive in other educational settings. A recurring question that concerns scholars and the general public is: to what extent is ethnic identity present within the contemporary social fabric (Bukovza, 2011)?

There are very few Arab teachers working in state-funded schools; equally low is the number of Jewish teachers working in Arab schools. In the 1980s there were a few attempts to integrate Arab teachers into Hebrew-speaking schools, but in some instances this was a failure (Brosh, 1995).

The Arab teachers 'fell into' teaching in Jewish schools almost randomly, out of financial need (as they could not find work in the Arab sector) and with no prior ideology or vision. As early as the 1980s there were a number of attempts to integrate Arab teachers into Jewish schools, but this were often not a success. Prior to 2005, there had been no attempt similar in scope to train Arab teachers to teach Arabic in Jewish schools, claiming that the cultural gap would not permit an Arab teacher to be accepted into the system (Brosh, 1995). Since the teachers have a consolidated worldview and a strong desire to be goodwill ambassadors, they can bring benefit to the educational process (Fragman, 2014).

Currently, the program of integrating Arab teachers into Jewish schools is called 'A- Salaam'; it is a program for teaching Arabic in $5^{\text {th }}$ and $6^{\text {th }}$ grades adopted by the Ministry of Education. All the teachers in the program are certified Arabic language teachers who have received additional training under the supervision of the Ministry of Education. The program is currently running in some 200 schools and the Ministry of Education has made it mandatory in the city of Haifa and the northern district. The program includes the regional Arabic dialect spoken in Israel and the beginnings of reading and writing and vocabulary acquisition in Modern Standard Arabic as a mandatory subject in middle school. As of 2015, the number of Arab teachers teaching in Jewish schools will be significantly increased (to 500).

\section{B. Social identity}

A person's identity is composed of several ties of belonging and is constructed of several circles, each of which molds that identity (Shaked, 2006). All individuals possess a multiplicity of identities that are influenced by social and cultural environment and by the information they are exposed to (Gergen \& Gergen, 1988). According to social identity theory (Tajfel, 1981), an individual's identity is that part of the self that derives from how he or she evaluates membership in the group. Individuals aspire to attain and preserve a positive social identity largely based on positive comparisons with relevant out-groups. The theory stresses the power relations and the conflict between the minority group and the majority group (Mana et al., 2007). One of the main ways to improve social identity and self-esteem is the tendency of members of the minority group to see their intragroup as better than the group they are trying to connect to. At the same time, group identity is also affected by the degree of the individuals' identification with their own group and the appraisal afforded them by the out-groups. This appraisal might be positive or negative, and is determined because of a comparison to other groups according to parameters such as social power or socioeconomic status. When a minority group is perceived as being inferior to the majority group, its members might feel their social identity is threatened, they might develop a negative social identity and feel that their self-esteem is damaged.

Allport's (1958) contact theory claims that reciprocal activity between groups assumes that close, unmediated familiarity with the 'other' can promote understanding between groups, lead to changes in attitude, reduce prejudice and confrontation. It would therefore seem that integrating Arab teachers into Jewish schools might encourage what had not been achieved in Jewish-Arab co-existence encounters. Sagie, Steinberg and Fachiraldin (2002) note that in many Jewish-Arab encounters there is tension and dissonance between the suspicious political aspect and the interpersonal aspect, which might be much more positive. Such encounters usually affected the attitudes and values of the participants regarding the 'other' cultural group and gave rise to questions about identities and attitudes on both sides (Lev-Ari \& Mittelberg, 2002).

The question of forming an individual identity also includes the formation of a professional identity. During the construction of a professional identity, a person strives to reconcile positioning, roles and experiences in society to construct a consistent self-image. Similarly, a teacher's professional identity is formed through the myriad interaction with the students and teaching staff, a process that is not perceived as a casual by-product, but rather an element that should be developed intentionally (Mansur-Shahor, 2009; Kozminsky \& Kluer, 2012). In principle: 'Being a teacher is an integral part of who I am as a person' (Mansur-Shahor, 2009:177).

The actual choice of these teachers to teach where they do is reinforced by the fact that their beliefs and ideologies affect their teaching methods and the significance they ascribe to their teaching (Kozminsky \& Kluer, 
2012).

\section{Sense of self-efficacy}

What is the sense of self-efficacy and how is it developed?

The sense of self-efficacy is the internal belief a person has when confronting a new task about his or her ability to successfully perform the behaviors required to complete the task properly. It is known that the sense of self-efficacy may change from one area to another and from one point in time to another (Bandura, 1997). The family of origin is the primary factor that shapes the sense of efficacy. If the sense of self-efficacy achieved in childhood is high, it will not undergo dramatic changes over the years and it will become more of a personality trait. However, if the sense of self-efficacy that forms in childhood is low, it will become circumstantial. It is well known that people who have a strong sense of self-efficacy are confident of their ability to cope and so are not afraid to take risks or accept challenges. According to Bandura, (1997), the sense of self-efficacy is built on four sources of information: a) functional experience, i.e. successes and failures experienced when trying to perform a tasks or tasks similar to it. This is the most important source for creating a sense of self-efficacy since the information derived from experience is direct and immediate. b) Observation of role models - when people watch someone else with traits similar to their own succeeds in a task, they say to themselves - if he/she can do it, then so can I. When the role model both demonstrates and explains how the task can be done, the sense of self-efficacy is greatly strengthened. c) Verbal persuasion - this refers to the fact that a reliable person who is significant to the person who has to cope, someone who knows both the field of the particular task and the skills of the person who has to deal with it, verbally persuades the person that he or she is capable of completing the task and possesses the necessary skills to do so. If one interprets these symptoms cognitively as signs of fear or stress, the sense of self-efficacy will drop. However, if we teach that person to interpret them as signs of alertness and readiness that will help to optimally execute the task, then the sense of self-efficacy will rise. A decisive factor for the success of coping with risks and distress during childhood is developing a stable social connection with a caring and skilled adult (Egeland, Carlson \& Sroufe, 1993).

\section{The sense of self-efficacy and the cultural variant}

Bandura (1997) presents an ambiguous approach to the correlation between an individual's sense of self-efficacy and sense of cultural belonging. On the one hand, Bandura explained the difference between self-esteem and sense of self-efficacy and claimed that the two structures represent different phenomena. People may judge themselves as hopeless in terms of their ability to perform a particular task, without feeling any decline in their self-esteem, since their self-esteem is not contingent on successful performance of this task and vice-versa: individuals can perceive themselves as possessing a high level of self-efficacy in a particular activity, but without any sense of cultural pride and thus their self-esteem is not affected. Bandura (ibid) also claimed that very often people are treated as cultural stereotypes such as ethnic affiliation and not according to their individual personality. This attitude causes a decline in self-esteem despite their strong sense of self-efficacy in many areas. Thus, one judges one's own self-esteem according to a certain reference group, whereas self-efficacy depends on oneself, with no cultural dependence.

On the other hand, Bandura (1995) notes that the sense of self-efficacy has universal functions, a universal processes of development, and is not free of cultural aspects. He believes that it is often difficult to isolate the impact of the cultural variable from other psychological or sociological aspects such as individual tendencies, family differences and economic status, but one must not ignore cultural or gender diversity. Bandura also distinguishes between the sense of efficacy of immigrants who are trying to preserve their own cultures and those who are trying to assimilate. Moreover, he explicitly states that 'culture plays a crucial role in shaping beliefs and a personal sense of self-efficacy, not only because it has an impact on the sources of information of the members of the cultural group, but it also impacts the way the information is processed and analyzed" (ibid, $151)$.

Oettingen (1995) also discussed the possible impact of the cultural variant on the formation of the sense of self-efficacy. He claimed that two of the sources of self-efficacy determined by Bandura are clearly linked to the cultural variant of social status of the cultural minority group: a) past successes mitigates the effect of current failures on an individual's sense of self-efficacy; b) the success or failure of similar individuals, namely individuals of the same cultural group, influences a person's sense of self-efficacy. Through family, school the workplace and the community, culture also shapes the knowledge acquired and in fact - the nature of the choice of knowledge and cognitive considerations, thereby affecting the processes of acquiring self-esteem and the sense of efficacy. In an empirical study, Oettingen (ibid) found that the cultural diversity between societies is measured in four areas, each of which has an effect on the development of the sense of self-efficacy: In an 
empirical study, Oettingen (ibid) found that the cultural diversity between societies is measured in four areas, each of which has an effect on the development of the sense of self-efficacy: a) whether a society is collectivist or individualist - in collectivist societies, great weight is attached to the sense of group efficacy or the sense of self-efficacy for actions within the group framework; b) the degree of structural inequality of the society (the degree of social stratification); c) the degree of avoidance of uncertainty; d) the gender aspect - whether a society is male or female dominated.

In light of the multiple identities of a female Arab teacher in Israel, and in light of the conflicts that this multiplicity engenders for an Arab teacher working in a Jewish school, we chose to examine the case of one such teacher in order to learn from her personal story how her identity is formed and what mechanisms she developed to strengthen her sense of self-efficacy when coping with these conflicts.

\section{Methodology}

\subsection{Research Method and Description of Context}

The article is based on the case study of a female Arab teacher working in a Jewish school. This case might further understanding of this unique and complex situation of the teacher as a particular instance, but at the same time it is also a representative case.

The study has a dual purpose: first, to examine how she portrays her personal identity within the social fabric the one she comes from (Arab society) and the other she is moving towards (Jewish society). Second, to examine what mechanisms she has developed to strengthen her sense of self-efficacy when coping with the conflicts deriving from the clash between the Jewish and Arab identities in her role as teacher.

This is an interpretative study following the principle of an internal case study (Stake, 1995). The study aims to generate in-depth knowledge of the case in order to grasp its essence and gain insights that could be projected onto other cases with similarities or even differences. Processes that are revealed in an internal case study enable understanding of similar processes in other cases. The researcher's contact with the distinctiveness and complexity of the individual case enables understanding of the case within its context. This understanding enables the researcher to understand better the connection between cause and effect and often constitutes the foundation for new hypotheses and theories. However complex the case study might be, we focus on aspects that are relevant to the research question we have chosen to ask. One may relate to a case study as a method of organizing social information and data that preserves the special nature of the objects under study. According to another approach - with this method we investigate a phenomenon in the fabric of daily life where the boundaries between the phenomenon and what surrounds it are only partly defined.

The findings were gathered from the connection between the researcher and the subject, with sensitivity and understanding of the social context. From this we can understand that this is not an objective process. The explanations are subjective and are intended as an attempt to understand the phenomenon and its complexities.

\subsection{Research Questions}

\section{How does a female Arab teacher working in a Jewish school perceive her identity?}

2. What mechanisms enable her to strengthen her sense of efficacy vis-à-vis the conflicts that arise when her being and Arab encounters the Jewish environment in which she works?

\subsection{Research Procedure}

In the case study presented below, we focused on a female Arab teacher who is teaching a technologic subject metter in a Jewish high school by her own personal choice. The teacher was identified during a comprehensive study on a different topic. During the interview, which lasted about two and a half hours in a café of her choosing, she was asked to relate to the specific issue of being an Arab teacher in a Jewish school. This procedure is meant to provide data from the field of experience in daily educational interaction that establishes and presents a professional identity according to the narrator's sense of self.

\subsection{Data Analysis}

A qualitative-interpretative research method is based on multifaceted critical discourse analysis (Klein, 2010). Here we traced sociocultural connections and hidden meanings derived from them according to the principle of critical discourse analysis focusing on social problems (Gee, 2004; Van Dijk, 1991, 2001). Gee, (2004) studied different forms of verbal abuse towards minority groups deprived on the basis of ethnicity.

\subsection{Ethics}

The teacher consented to participate in the study; she was aware of the gathering of the data for the research and 
understood its aims. Identifying details have been deleted in order not to reveal the teacher's identity.

The teacher was interviewed by the first researcher. She was found through a mutual friend who was aware of a study being conducted at the same time by the same researcher. The teacher came prepared to the interview. She spoke enthusiastically about her life and the process of her work and at the end of the interview even introduced her family to the researcher. The teacher lives in a mixed town of Jews and Arabs, and as stated, teaches in an Israeli Jewish school. She is married with three children. She spoke willingly and in great detail about her life her childhood, her education, her parents, and, of course, the process of her acceptance into the school.

\section{Presentation of Findings and Discussion}

The question that interested us was the mechanisms that enable living with an identity conflict. The teacher (she is referred to thus in order to avoid identification) says: "I define myself as an Arab who grew up in a Jewish environment." She declares her identity as an Arab, but the fact that in the same sentence she mentions that she grew up in a Jewish environment suggests that she recognizes the fact that the Jewish environment is a component of her identity. Since this is the case, what helped her gain acceptance in Jewish society? What mechanisms did she use to strengthen her sense of self-efficacy in the cultural encounter between being Arab and the Jewish environment she works in? These mechanisms can be viewed as concession and concealment versus ones of prominence.

The mechanisms of concealment touch upon three issues: relying on an outward appearance that is not typical of Arabs, concealing typical Muslim clothing and behavior, and avoiding situations of conflict.

The mechanisms of prominence are: the respected position of the father among Jews, adopting a multicultural worldview and excellence in areas that might be problematic in terms of identity.

Each of these mechanisms will be discussed separately.

\section{Outward appearance similar to the Jewish environment}

The teacher explains how being an Arab in a Jewish environment was not a problem when she was young, because, in her opinion, neither her outward appearance nor her first name indicated she was Arab. Her appearance was not typically Arab: "We went to Israeli schools. They looked at us and didn't see anything because we were redheads, so everyone said 'we don't see anything'. We look like that because of our mother's family, who came from Lebanon, our cousins have blue eyes, so I am not surprised by the reactions of 'you don't look it'". Her name was adapted to an Israeli name: "I was not identified as an Arab. My name has the same letters as a Jewish name. When I came to the school as a child, the school secretary wrote down my name and it stayed like that. In most cases it was my entry key. ... Well, I was always accepted as a fun person, until they discovered I was Arab. If they accepted me anyway as I was, because they already knew me and saw there are good Arabs who look good and are talented. There is a stigma - an Arab should look like .... an Arab should be working in ....".

The fact that her outward appearance and name, which are the first features of identity we all encounter, were such that they did not give away her Arab ethnicity helped her be accepted into Jewish society, at least initially. Later on, once people were familiar with her personality and discovered she was 'fun', the fact she was an Arab was no longer an issue because she had been treated as the person she was regardless of where she came from. In other words, the first mechanism that enabled her to live in peace with two identities was giving up her original name as a child and adapting it to a Jewish name, and the genetic fact of being light-skinned. Nevertheless, she notes that initial outward acceptance is insufficient, both for her and for her surroundings: "I have a sense of being an outsider. Outwardly, no one will recognize me as an Arab, but as soon as they know there is a change." The Jewish students she teaches are also captives of a stereotypical mindset: "When the students hear I am an Arab they are in shock. They immediately say I don't look it." In other words, even though her name is pronounced like a Jewish name, and even though she does not look like an Arab, as soon as people in the Jewish environment find out, the initial reaction is one of surprise and a change in attitude. Only later, once they get to know her personality, does the stigma become blurred.

\section{Awareness of the inner truth about concealing outward signs of Arab and Muslim identity}

The teacher spoke about the people in her immediate surroundings who adhered to the Muslim religion and customs in order to preserve their identity within the Jewish environment. Her mother observed religious customs for the sake of her children: "Mother observed the Muslim customs and holidays so that we would not lose our identity. She observed everything, even though she was not religious." About another female relative she said: "My relative and friend wears a veil-a burka, and my sister-in-law wears a head covering. Religious teachers, so she became like this out of shame, but not because it is her inner belief." And about another teacher, "I know another 
teacher who lives in Ashkelon, she teaches physics, but it was important to her to emphasize the fact she is Arab. She spoke loudly and said 'I am an Arab' \{stressing the words\} and so people looked at her, what do people care if they know who I am."

The teacher is explaining to herself that outward signs of being a Muslim Arab are not important; what is important is inside: "I am at peace with myself, because the thing is not about dress but about inner belief." Nevertheless, like her mother before her, she still keeps some of the religious traditions of Ramadan for the sake of her own children: "Another thing I would like to stress is that I am a Muslim and not a Christian. There is also the stigma of not being a good Muslim, not observing Ramadan, just the celebration feast I conduct so that my children know."

3. Avoiding conflict

One of the mechanisms she uses to avoid conflict between her Arab identity and the surrounding Jewish life is staying away from 'pitfalls': "not to get into political discussions - I don't discuss politics, I don't talk about the lynching or about the intifada. I try to generate interest is what is special about me. Ifeel that the children like to be around me". She refrains from talking to her Jewish students about harsh events taking place in Israel because of the national conflict such as the Arab lynching of two Israeli soldiers who got lost and found themselves in an Arab area, or the two intifadas (uprisings) during which many Jewish civilians in Israeli cities in were murdered Arab suicide bombing attacks. This avoidance lessens the risk of friction. She also avoids talking about political issues with her own children, such as the 'Nakba' - the term Arabs gave to the establishment of the State of Israel, which they perceive as a catastrophe: "My children don't seem to know the term 'Nakba'. We don't talk about it because it is not relevant to daily life. At my sister-in-law's they do talk about it because at her school the term comes up. I don't think of bringing it up, maybe it's a kind of ignorance, but it doesn't bother me."

Another strategy she used is to turn pain into humor - the term 'Arab work' is used by Jews to signify low-quality work. She mentions that she uses humor when referring to this term. She allows herself to do this because it is clear to her that she does her job very well, and no-one would dare speak to her about doing poor work. Humor allows her to both neutralize the offense inherent in this statement and to reflect it back on the Jews, thereby extracting the concept from the stereotypical mindset: "The concept 'Arab work' - I have turned it into a kind of joke, because I do things the best. And then they say 'did you forget our teacher is Arab', even the new teachers know. With us what you do mean - with us, reactions from parents, there was one mother who expressed herself stigmatically: 'do you want to be like an Arab workman', but as soon as they remember, they swallow their tongue When they know me they are careful."

1). The respected position of the father in Jewish society

The teacher recounted that her father's family is highly respected among the Jews, "I was born in a southern town in Israel. My parents are from a very well-known family in Jerusalem, much respected in Jerusalem, and very well-known in my town. Before the state, my father was a farmer in the town where he was born. During the war of 1948 the family hid in wells. Today in my town there are Arabs who came from the Triangle (an area in the center of Israel with many Arab villages)], mainly doctors. But at one time we were the only family. I had an arranged marriage with a cousin and I moved to Ramle. Everyone respected my father. He was very hospitable, a warm person $\{. .$.$\} the values in my father's house were such that we all loved everyone and everyone in the$ town loved my father." The father's personality, his tolerance, and his esteemed status led to acceptance and respect also from the Jews living in the town. She is also aware of the fact that in Israel there are towns in which the relationship between the Jews and the Arabs are different and far less cordial: "We grew up reasonably well among the Jews. It was not radical like in Ramle and Lod \{mixed towns\}. The father's respected status allowed them to live among the Jews and be treated 'reasonably well'. As a result, the tension between her identity as an Arab and living among Jews was diminished."

2). Adopting a multicultural worldview

One of the principles of a multicultural perspective is to respect people, whoever they may be. The teacher adopts this perspective towards others and she broadcasts this to her surroundings so that she should also be treated in this manner: "I live as a multicultural woman - that is my basic nature!" and elsewhere she says: "I will always find how to reconcile with those around me. I am comfortable with compromise, and then I get the same treatment. I will keep my distance from anyone who is hostile."

She talks about incidents in which she treated others with dignity and those in which there was an obvious difference between her and the other person in terms of religion: "When I was studying at the University $I$ located a group of girls who were all writing a seminar paper. I know that one of the girls was religious and so I bought disposable plates and cutlery, so she would feel comfortable and be able to eat and keep kosher. She was 
in shock, but I explained that it was my approach to respect everyone." Even when in most instances Arabs in Israel express their objections to the Jewish state and its symbols, and Jewish society accepts this with understanding, such as their objection to singing the national anthem, Pirhia behaves differently: "I sing Hatikva the Israeli national anthem\}. I stand to attention when they raise the flag; it is out of respect, because I would stand if I were somewhere else." Another example that might invite an identity clash is the following. "I build scenery for the ceremonies. That's my part. I relate to it as artwork, I don't care if it Holocaust Remembrance Day or Soldiers' Memorial Day, because I look at the creative aspect, the artistic one." Her ability to neutralize the loaded national, historical content of Judaism and the State of Israel enables her to be comfortable with the tasks she is asked to perform as a teacher working in a Jewish school. She explains that she respects everyone, and so she won't do anything hurtful, and she anchors her behavior in the values she grew up with: "My behavior comes from home; I haven't changed in any way. It makes no difference whether it is a Jew or an Arab. Good treatment is a kind of 'super-virtue' that neutralizes anything that does not whiff of respect for another person." Even when she was part of the school delegation to Poland, where most of the Jewish people were exterminated in the Holocaust, she did not take a stand as an Arab, but as a human being: "I was part of the delegation to Poland - a multinational delegation with Arabs and religious Jews, and so they called it multinational. By definition this is a very tough delegation. The emphasis is on the content. Here it was necessary to find a balance and speak to everyone's heart..." and she sums up her approach: "I am talking about the human being, not in terms of Jews and Arabs. There are bad Jews and there are bad Arabs. I do not radicalize."

3). Excelling precisely in those places that are problematic in terms of identity.

She had plenty to say about educating towards enlistment in the IDF. She spoke about her activities in relating to bodies connected to this process: "Joining the army - in the first year that I taught about army readiness there was a staff meeting about how to do it. I did not serve in the IDF. I arranged a 5-hour workshop. It turned out, all of a sudden, that one of the homeroom teachers had done national service a non-military alternative for religious girls such as teaching or working in hospitals etc and didn't have a clue about IDF concepts. The two others and myself had no idea. I studied everything as best I could. I went into websites and learned all about it. I really did it seriously; on the day the guys from the army came I wasn't present because it was my day off. They went into my class and the board was packed with information. The kids in the class knew and cooperated. They left the class and went to tell the principal that in my class the homeroom teacher had done a wonderful job. The principal told them I was Arab and they were in shock. They said they had to meet me... He introduced me to the officers and they were astonished by my instruction. The principal was proud. At the Gadna (cadets base) I had no problems getting in or staying there. When there are national ceremonies I make sure to send my child to school so they don't say he's not there because he is an Arab..." The teacher, it seems, has a need to demonstrate her loyalty and excellence specifically at events linked to Jewish-Israeli identity and makes sure that her own son is brought up the same way.

But there are still problems...

While she was speaking, there was a very obvious gap between her Arab origin, which defines her sense of personal identity and her presentation of her Israeli identity that seems to erase her ethnic Arab identity. She is aware of her personal dilemma, which extends into the family circle: "My daughter, who is in an Arab preschool, is becoming ambivalent about her identity. She doesn't want to speak Arabic in the preschool.” Elsewhere she says: "My sister, for example, her husband insisted that the children study in Arab schools. My husband doesn't care where the children go to school... the children prefer to speak Hebrew. At home we speak both, but when we visit the family where the language is Arabic, they make fun of the children and say that they talk like Americans speaking 'broken Arabic'”. She mentions that her actions seem to have damaged the younger generation. Awareness of the problem of identity is explicitly stated. The teachers' sense of power relies on the fact that in contrast with her nuclear affiliation, she sees the comparative (Jewish) reference group, in other words, a group in which a person relates to its culture, but does not aspire to join it.

Another difficulty is "removing the mask" as soon as there is a terror attack carried out by Arabs in which Jews are injured: "Madeleine, my neighbor from the town I grew up in was always very helpful, but as soon as there was an attack, Madeleine would take all her anger out and express every stigma. Politics steals negative resources, an attack, a mention of the fact that we live well; a good friend of mine who lives in the West Bank says to me 'you are more protected than we are "'. In other words, it is possible to maintain good neighborly relations with Madeleine, who is Jewish, as long as there is quiet, but her pain and rage when there are terror attacks give rise to the expression of all the negative stigmas about Arabs. Pirhia does not clam that such statements are directed at her personally, but the fact that she belongs to the group of Arabs certainly creates difficulties in the face of such declarations. Another of her difficulties is vis-à-vis the Arabs themselves: "My identity is Israeli. Arabs see us as 
traitors. Personally, I am afraid to walk around in Ramallah. Ifeel that my identity will appear to be not Arab, I am scared. People look at me and don't see me as Arab." She cannot belong to Jewish society because she is Arab, but the Arabs see her as a traitor because she lives in peace with the Jews.

Other difficulties arose in her professional life as a teacher. "At first I wanted to get into an Arab school - the principal looked at how I was dressed; I explained that I grew up in Ashkelon, and that my clothing was not the issue. It didn't work out, so I decided to go back to My previous school Here her 'non-Arab' style of dress caused the principal not to hire her even before getting to know her as a person. She does not talk about her emotional reaction to this rejection, but reports in a matter-of-fact style that she went back to the school she had been working in before.

What helped her cope with these difficulties was the support she enjoys from her Jewish colleagues: "The school staff offered a lot of support and so it did not occur to me to leave the setting of a Jewish school". But at the same time, she felt people were suspicious of her: "The staff room - I walk in and there is silence, it is a kind of unpleasantness, or perhaps respect. I try to look at the positive half of the cup". She also draws strength from the inner sense of mission that drives her. It is the mission to shatter the stereotypes of Arabs and facilitate Jewish-Arab coexistence: "I teach in a Jewish school, but my sisters teach in Arab schools. There is a shortage of teachers in the Jewish sector and so we are here. In doing so we shatter stereotypes". She also says: "I am an example of co-existence", "I receive a lot of positive reactions from the children's parents. They see that they enjoy learning and they really do learn. Most of them think this is important. They keep on saying in Israel there are many Arabs and it is important to know how to communicate to strengthen the ties and bridge the gaps".

\section{Conclusion}

The advantage of a case study is that it helps gain deeper understanding of situations that we do not always examine in an appropriately complex manner, because in our routine activities is it easy to slip into a pattern that silences spaces of discomfort. The complex social and political state of Israeli society is ever-present in the classroom and the staff room, not to mention the street. Arar, Khalid and Massry-Herzllah (2016), describe the factors influencing teachers' motivation in the Arab education system in Israel. (1) Arab culture, (2) the school climate and (3) government policies. Arab teachers try to meet both government requirements and the minority Arab society's expectations that they will shape students' academic achievements, national identity and culture. Deficient resources and Arab principals' detached management styles augment the difficulty, negatively influencing teachers' motivation. Suggestions are given to improve government policies and Arab principals' work and thus to enhance teachers' motivation.

Choosing to teach in a cultural space that is not your own takes courage, as well as great moral courage (Kidder, 2005), since the speaker declares she remains loyal to her opinions, principles and worldview at all times. She tries to prove that she is not part of the stereotype that Jews have of Arabs. She relates to what happens in the staff room while mentioning the political scenario, but then coping with Israeli reality brings up mindsets or attitudes about co-existence which, even if she describes them as easy to manage, there are situations that undermine this, such as a terror attack. In the study we sought to understand her state of mind, mainly in light of the scarcity of Arab teachers working in Jewish schools, even if it is the intention of the Ministry of Education to increase this phenomenon in the coming years (Huri, 2012). This teacher's act still indicates the existence of narrow margins that can shed light on what other teachers might encounter in the future as they enter the system (Baratz, 2016).

The essence of conduct in terms of personal identity is often linked to the teacher's social circles. Her parents' and her husbands' homes, and the second is the work circle. In this process, personal identity oscillates between acceptances on the one hand, and on the other, the pain of weakened identity linked to traditional Arab society. The professional identity of the interviewee is very clear to her; she adheres to the curriculum, which dictates her educational practices: avoidance of discussion about politics, presenting learning materials in the best possible way and adapting to the demands of the system. Her conformist behavior strengthens her professional identity and does not require her to face the issues of personal choice, but in-between, there are signs of that oscillation between the personal sense that stresses the ethnicity of being an Arab, and the professional space where there should be no signs of any ethnic affiliation.

Her work in a Jewish school creates an important perspective that needs to be considered: how do the Jewish students, teachers and parents perceive her. It seems that the sense of professional identity is strengthened by the fact that she feels she is on a mission in whom her role is to combat stigmas. In her words, she is helping to shed light on the figure of the authentic Arab living in Israel. She is a kind of cultural bridge to Israeli society precisely because of her actions on Soldiers' Memorial Day or by going with the students to Poland. According to the definition of Kidder (2005), this teacher had educational moral courage, because the dimensions of her boldness, 
maintaining her personal and professional principles are what guide her. Her personal and professional conduct unite the cultural principle suggested by Berry (2003), which stresses that integration of a cultural minority group into the public space can succeed only when the minority group is interested in it, and when the majority society is open and interested in including the minority group. But the frustrated sense of identity is summed up by the teacher in the sentence: "Who am I really if my children speak broken Arabic?"

The second research question relates to the mechanisms that help strengthen Pirhia's sense of self-efficacy in successfully handling her identity conflict. The first source, according to Bandura (1997), is functional success. Another source that reinforces the sense of efficacy, according to Bandura (1997) is a role model. The teacher's stories show that her father was a role model for her in terms of his ability to live in peace and earn respect and esteem from his Jewish environment. As the literature suggests for a source that reinforces the sense of self-efficacy, her father is a skilled adult who gives emotional support and guidance, encourages values and is a personal example of various ways of coping, and generates endless opportunities to experience efficacy. Observing him as a child enabled her to learn how an Arab can live among Jews, and have good neighborly relations and earn their respect. This assistance builds trust, skills and the sense of personal ability (Werner \& Johnson, 2004). The other two sources Bandura mentions in his theory, verbal persuasion and physiological arousal, were not evident in the interview. Verbal persuasion was not an issue since probably either the Arab environment does not persuade her that she can cope successfully with Jewish society or because she does not convey any need for such encouragement, or because her Arab environment has reservations about her being an Arab teacher in a Jewish school. Physiological arousal does not usually appear in interviews because these are experiences that speakers feel physically when confronting new and threatening tasks, and when that moment passes, it is no longer deemed significant in the experience of building their sense of self-efficacy (Kass, 2012).

Another view of the teacher's sense of self-efficacy when confronting her identity conflict emerges from the analysis of what she says and the understanding that she uses mechanisms of concealment and prominence. Thus she uses her external physical features which are similar to the Jewish environment in order not to stand out as being different. She rationalizes this and convinces herself that what is important is her awareness of the inner truth, even at the expense of hiding any outward signs of being Arab and Muslim. Finally, she avoids conflicts with her Jewish and Arab environment, thereby exposing herself less to the differences and tensions between the two identities. Her mechanisms of prominence are intended to create a bridge between her identities. This is a human and universal bridge that is not exclusive to any particular identity, but rather to the fact of being human being. The aspiration to excel and achieve a status of respect through the figure of the father and through her own actions enables her to minimize tension between being an Arab and working in a Jewish environment. Her sense of professional efficacy relies on universal parameters such as her seriousness towards her profession, her dedication even when the contents are nationally Jewish, such as enlistment in the IDF. The multicultural worldview she has adopted enables her to treat every human being with respect, regardless of religious or national identity, thereby avoiding possible conflicts.

\section{References}

Al-Haj, M. (1997). Identity and orientation among Arabs in Israel: A state of double periphery. Medina, Government and International Relations, 41-42, 103-122 (Hebrew).

Allport, G.W. (1958). The nature of prejudice. Doubleday Anchor Books: New York, Chapter 30, pp. 444-462.

Arar, H., Khalid K., \& Massry-Herzllah, As. (2016). Motivation to Teach: The Case of Arab Teachers in Israel. Educational Studies, 42(1), 19-35. http://dx.doi.org/10.1080/03055698.2015.1127136

Bandura, A. (1995). Self-efficacy in changing societies. NY: Cambridge University Press. http://dx.doi.org/10.1017/CBO9780511527692

Bandura, A. (1997). Self-efficacy - the exercise of control. New York: Freeman.

Baratz L. (2016). Moral courage from the perspective of Arab teachers in Jewish schools. Intercultural Education. 27(1), 39-53. http://dx.doi.org/10.1080/14675986.2015.1128722

Baratz, L., \& Reingold, R. (2013). Moral courage - an essential component for teachers' continuous professional $\begin{array}{llllll}\text { development. Procedia - Social and Behavioral Sciences, } & 76, & \text { 89. }\end{array}$ http://dx.doi.org/10.1016/j.sbspro.2013.04.079

Berry, G. (2003). From melting pot to multiculturalism: Implications for higher education and the training of welfare and education professionals. In A. Leshem \& D. Roer-Strier (Eds.), Cultural differences as a challenge for human services (pp. 113-125). Jerusalem: Hebrew University, Magnes (Hebrew). 
Breakwell, G. M. (1986). Coping with threatened identities. London, Methuen.

Brosh, H. (1995). The Arab teacher in the Arab school. Education and Its Surroundings, 17, 97-116 (Hebrew).

Bukovza, G. (2011). Ethnic identity and stereotypes in Israel, differences between Ashkenazi and Middle Eastern Jews and between age groups. Society and Welfare: Social Work Quarterly, 31(4), 607-633. (Hebrew)

Central Bureau of Statistics. (2012). The Moslem Population in Israel - data for Eid el-Adha, Press release, 15.10.2010. Retrieved November 29, 2012, from http://www.cbs.gov.il/reader/cw_usr_view_SHTML?ID=802 (Hebrew)

Egeland, B., Carlson, E., \& Sroufe, L. A. (1993). Resilience as process. Development and Psychopathology, 5(4), 517-528. http://dx.doi.org/10.1017/S0954579400006131

Fragman, A. (2014). The integration of Arab native teachers as teachers of Arabic in Hebrew-speaking schools: Intended policy or arbitrary strategy?. Maof u'mase, 16, 133-164 (Hebrew).

Freire, P. (1998). Teachers as cultural workers- Letters to those who dare teach. Boulder, Colorado: Westview Press.

Gee. J. P. (2004). Situated language and learning: A critique of traditional schooling. London: Routledge.

Gergen, K. J., \& Gergen M. M. (1988). Narratives of the self as relationship. Advances in Experimental Social Psychology, 21, 17-56. http://dx.doi.org/10.1016/S0065-2601(08)60223-3

Haj, M. (2002). History curriculum for Jewish and Arab schools in Israel: Ethnocentricity versus controlled multiculturalism. In A. Ben-Amos (Ed.), History, identity and memory: Past images in Israeli education (pp. 137-154). Tel Aviv: Ramot (Hebrew).

Huri, G. (2012). Female Arab teachers to be integrated into Jewish schools. Retrieved from http://www.haaretz.co.il/news/education/1.1724420 (Hebrew).

Kashua, S. (2005). So humiliating this name, Israeli Arabs. Eretz Acheret (Hebrew).

Kass, E. (2012). Not to fear fear itself - A sense of personal and professional self-efficacy in teaching. Tel Aviv: Mofet Institute (Hebrew).

Kidder, R. M. (2005). Moral courage: Ethics in action. New York: Harper Paperbacks.

Klein, A. (2010). Analysis of critical discourse of newspapers. In L. Kasan and M. Krumer-Nevo (Eds.), Qualitative investigation data analysis (pp. 230-254), Ben-Gurion University Publishers (Hebrew).

Kozminsky, L., \& Kluer, R. (Eds.). (2012). Constructing the professional identity of teachers and teacher educators in a changing reality. Tel Aviv: Mofet Institute (Hebrew).

Lev-Ari, L., \& Mittelberg, D. (2002). Identity and reciprocal relationships between Jewish and Arab students in Oranim College: Towards a multicultural education. Retrieved March 6, 2014, from http://www.oranim.ac.il/con4_t_researcher/abstracts_lev_ari.htm (Hebrew).

Ma'aluf. A. (2010). Lethal identities. Nahar Sefarim Publishers (Hebrew).

Mana, A., Or, A., \& Mana, Y. (2007). Social representations, social identity theories, and the intercultural encounter: An integrative model of adolescent new immigrants' social construction of identity. Megamot [Trends], 45(1), 24-52 (Hebrew).

Mansur-Shahor, H. (2009). Narrating an identity - The development of personal and professional identity. In Y. Barak \& A. Gidron (Eds.), Active educational cooperation (pp. 167-186). Tel Aviv: Mofet Institute. (Hebrew).

Oettingen, G. (1995). Cross-cultural perspective on self-efficacy, in Bandura, A. (Ed.) Self-efficacy in changing societies (pp. 149-171). Cambridge: Cambridge University Press. http://dx.doi.org/10.1017/CBO9780511527692.007

Peres, Y., \& E. Ben-Rafael. (2006). Cleavages in Israeli Society. Tel-Aviv: Am Oved and Sapir Library (Hebrew).

Sagie, S., Steinberg, S., \& Pachiraldin, M. (2002). The personal and collective self in an intergroup encounter: Joint workshops for Jewish and Arab students in Israel. In L. Kassan, \& R. Lev-Vizel (Eds.), Group work in a multicultural society (pp. 41-59). Tel Aviv: Barkai (Hebrew).

Shaked, G. (2006). Identity: Jewish literature in foreign languages. Haifa: Haifa University (Hebrew). 
Shkedi. A. (2003). Words that try to touch, a qualitative study - theory and practice. Tel Aviv: Ramot Publications. (Hebrew).

Stake, R.E. (1995). The art of case study research. Thousand Oaks, CA: Sage.

Tajfel, H. (1981). Human groups and social categories. Cambridge, Cambridge University Press.

Van Dijk, T. (1991). Racism and the Press. Routledge. In D. Tannen, D. Schiffrin \& H. Hamilton (Eds.), Handbook of London and New York.

Van Dijk, T. (2001). Critical Discourse Analysis. Discourse Analysis. (pp. 352-371). Oxford: Blackwell, 2001 (Longer version on homepage).

Zupnik, J. Y. (2000). Israeli - Palestinian 'dialogue' events. Journal of Discourse Studies, 2(1), 85-110. http://dx.doi.org/10.1177/1461445600002001004

\section{Copyrights}

Copyright for this article is retained by the author(s), with first publication rights granted to the journal.

This is an open-access article distributed under the terms and conditions of the Creative Commons Attribution license (http://creativecommons.org/licenses/by/4.0/). 